\title{
Knowledge Sharing and Business Performance: The Role of Innovative Behavior
}

\author{
Endang Sulistiyani ${ }^{1, *}$, Karnowahadi $^{2}$, Dody Setyadi ${ }^{3}$ \\ ${ }^{1}$ Business Administration Department, Politeknik Negeri Semarang, Semarang, Indonesia \\ ${ }^{2}$ Business Administration Department, Politeknik Negeri Semarang, Semarang, Indonesia \\ ${ }^{3}$ Business Administration Department, Politeknik Negeri Semarang, Semarang, Indonesia \\ *Corresponding author. Email: endangsulis15@polines.ac.id
}

\begin{abstract}
The purpose of this study was to analyze the antecedent variables that affect business performance in the handicraft sector SMEs in Central Java. The population of this study are all owners of handicraft SMEs in Central Java. Samples were taken using purposive sampling method. Data were collected through questionnaires, and processed using Structural Equation Modeling analysis. The loading factor value of each indicator on the latent variable shows a significant value. Based on the results showed a significant positive effect on the direct effect of knowledge sharing on innovative behavior, and innovative performance behavior on business performance. The direct relationship of knowledge sharing on innovative behavior shows the dominant influence value. The indirect effect of knowledge sharing on MSME business performance is mediated by innovative behavior. The results of this study contribute to strengthening social capital theory, the concept of organizational citizenship behavior, resource based view and knowledge based view theory.
\end{abstract}

Keywords: knowledge sharing; innovative behavior; business performance.

\section{INTRODUCTION}

Knowledge sharing practices are carried out by actors and members of business organizations through various media to coordinate work, make decisions, find and solve related problems. Knowledge sharing is very crucial in identifying, creating, retrieving, collecting and developing knowledge as well as improving the capabilities and performance of individuals and organizations. Several studies have stated that knowledge sharing is believed to have an impact on business performance [1]-[3]. Study [4], found the relationship of knowledge sharing to various service based organizations in Turkey through knowledge management. However, several other research results show whether or not there is an influence between knowledge sharing on organizational performance [5]. Study [6] found no significant effect between explicit knowledge and operational performance. Based on the research problems that have been described originating from previous studies, it is how to build an empirical research model to overcome the gap between knowledge sharing and business performance through innovative behavior.
Indonesia through the Ministry of Industry has developed the "Making Indonesia 4.0" initiative to implement the 4IR strategy and Roadmap in Indonesia. This Roadmap involves various stakeholders, ranging from government institutions, industry associations, business actors, technology providers, as well as research and educational institutions. The Making Indonesia 4.0 Roadmap provides clear directions and strategies for the movement of Indonesian industry in the future, including in five sectors that are the focus and 10 national priorities in an effort to strengthen Indonesia's industrial structure, one of which is the empowerment of MSMEs.In Central Java, the number of MSMEs has reached 147 233. Contribution to Gross Regional Domestic Product (GDP) has increased, in 2016 it contributed 4.98 percent, 2017 was 5.26 percent, and 2018 was recorded at 5.23 percent, 5.86 percent in 2019 , and decreased drastically -33.15 percent in 2020. The number of workers absorbed until 2019 was 1,094,944 people. MSME Asset Data in 2019 reached 21,250 billion and the turnover generated was 57,988 billion. 
In the current era, Micro, Small and Medium Enterprises (MSMEs) have decreased the number of poor people in Central Java by 63,830 people as released by the Central Statistics Agency (BPS) recently, which is an encouraging achievement. Of a number of provincial government programs in poverty alleviation, MSMEs have a major role. Because, if poor people get the skills and capital so they can start MSMEs, they will get a continuous income. In fact, they can employ women. This is proof that the contribution of SMEs to the economy is getting bigger. So that the MSME sector becomes a savior when the economy is turbulent. Like now, when the corona virus really hit the trade sector which resulted in a slowdown in the global economy, strengthening MSMEs was absolutely necessary. One of the MSME categories is the handicraft industry. The next sub-sector of art is craft or also commonly called craft. Craft is a creative activity related to the creation, production and distribution of products made or produced by craftsmen starting from the initial design to the process of completing the product directly from the hands of the craftsman. The results of handicraft products in the form of handicrafts made of precious stones, natural and artificial fibers, leather, rattan, bamboo, wood, metal (gold, silver, copper, bronze and iron), glass, porcelain, cloth, marble, soil clay, and lime. Handicraft products are generally only produced in relatively small quantities (Limited edition). Craft is one of the sub-sectors of the creative industry, but in contributing to the national GDP, Central Java is still below West Java, East Java, Yogyakarta and Banten.

Based on the gap research and the gap phenomenon above, this study wants to contribute to how SMEs in the handicraft sector in Central Java have the capability to strengthen and improve their organizational performance through innovative behavior. The concept of this integrated solution is characterized by understanding the problem, analytical skills, the ability to create creative ideas, the ability to collect facts that support the idea, the ability to make conclusions and the ability to understand the opinions of others who support the idea.be an asset in improving the performance of MSMEs.

\section{LITERATURE REVIEW}

\subsection{Knowledge Sharing and Innovative Behavior}

Knowledge sharing enhances the ability to explore knowledge in the learning process. This was done through formal and informal discussions to find alternative solutions. Knowledge sharing leads employees to new discoveries in terms of ideas, techniques, rules, skills and experience. Knowledge sharing is able to create creative ideas [7].

The capability of organizational members to develop new competence, to produce creative solutions, and to socialize the knowledge about that, as stated by [8], and also the capability not only to think conducively and conveniently without pressure but also to think energetically and spontaneously, as asserted by [9], all will take organizational members to innovative performance. Employees who are given autonomy and able to develop creative ideas spontaneously will always be able to implement innovative behavior. Knowledge sharing can create extra role creativity behavior, because both are carried out based on pro-social behavior. extra-role creativity is an antecedent of implementing innovative performance in creating products, work processes and work results that have unique differences [10]. Knowledge sharing among members or perspectives in task-related debates, teams can discuss disagreements and promote organizational learning there by establishing a common understanding for task assessment or decision making. Therefore, task conflict can be managed well by increasing knowledge sharing.Integrating knowledge and skills for selfadvancement, feeling of continuous learning as a personal need and mastering ways for coping with organizational challenges as Intrinsic work values [8]. The following hypothesis is proposed:

H1: knowledge sharing positively influences innovative behavior

\subsection{Innovative Behavior and Business Performance}

Innovative work behavior is a multidimensional form of superior performance, in it there is an idea generation dimension, namely, introducing creative ideas, promotional ideas, and always try to get support for the implementation of the ideas that has been suggested [11]. Innovative work behavior generates commitment work is an attitude that shows selfmotivation and personal commitment to innovative ideas and there is a desire and action to implement the ideas these become real work practices with novelty The existence of mutual trust, the availability of adequate information technology, the support of the leader will create learning in the organization [12]. A comfortable working environment in exploring bright ideas in creating new work practices enhances innovative behavior. In innovative work behavior, the meaning of work values includes:work process updated through well-organized information through 
interaction within the teamwork, recognition of selfcompetence as an extrinsic work value. Get empowered personal capability an influencing person for helping the others in the teamwork as a prestige work values cultivated in a team member [8]. Innovative performance is a multidimensional concept, and one of constitutive dimensions is generating ideas [13]. This dimension is about introducing creative ideas, promoting those ideas, and always seeking support for the implementation of those ideas [11],[13]. Innovative performance can produce work commitment, which is an attitude to show self-motivation and self-commitment toward innovative ideas, and also to indicate self-willingness to implement those ideas and its revision at workplace. It was said by [14] that innovation and ongoing organizational improvement must be fully supported by employees. The capability to change original ideas into phenomenal works that are useful to complete the jobs at group and organization is referring tominnovative. the following hypothesis is proposed.

H2: innovative behavior positively influences business performance.

\section{METHODOLOGY}

The population of this research is the owner of SMEs in the handicraft sector in Central Java. The criteria for the MSME sample used in this study are MSMEs have been established for more than 5 years, and the owner has experience in business; more than 3 years, the owner's education is at least high school, and often receives training from various training places about MSMEs. Some of the data collection processes carried out by this research data are as follows: Questionnaires, Observations, Literature studies of handicraft MSME owners who have established their business for more than 5 years, and routinely attend training conducted by the Central Java Training Center and MSMEs. According to these criteria, a sample of 295 data was collected.

The researcher provides information about the purpose of the study to identify perceptions about the item with questions. The validity and reliability of the questions have been tested by previous researchers. All items are rated on a ten-point scale ranging from 1 , "strongly disagree" and "strongly agree to 10 .

\section{RESULTS AND DISCUSSION}

The structural equation model test was carried out after testing the validity and reliability of the constructs with the confirmatory model factor analysis. This test is carried out to obtain a structural model that meets the goodness of fit rule. Figure 1 presents the structural relationship model generated. Indicator validity is measured by convergent construct validity. This can be seen from the value of the loading factor in each latent construct. The loading factor value is said to be statistically significant if the value is above 0.50 [15], indicating the magnitude of loading factor is well mirroring the constructed variable. The estimation results of the construct model are obtained by Chi-square with a value of 135.813. Other fit criteria $\mathrm{GFI}=0.931$, $\mathrm{AGFI}=0.906, \quad \mathrm{NFI}=0.942$, $\mathrm{CFI}=0.965$, TLI $=0.960$ and $\mathrm{RMSEA}=0.067$ have recommended conformity standards. Table 1 shows that regression coefficient of the hypothesized path $\mathrm{H} 1$ $=0.894 ; \mathrm{H} 2=0.841$; with the $\mathrm{P}$-value $<0.05$, indicating the acceptance of all hypotheses in the model.

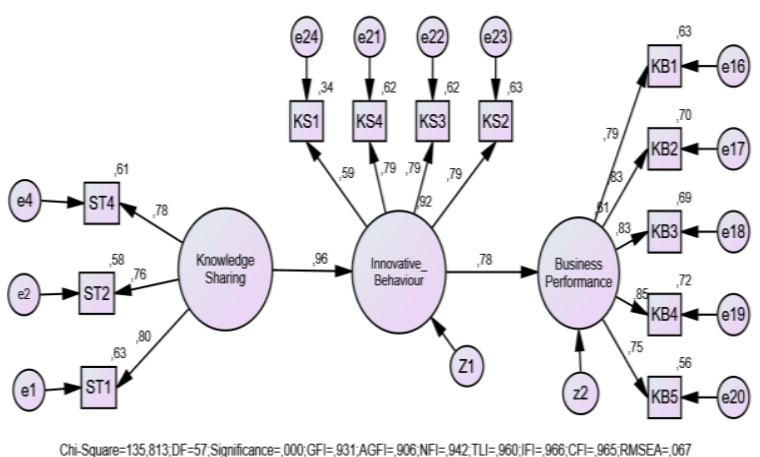

Figure 1. Structural Relationship Model

Table 1. Estimated Value of Direct Effects Between Variables

\begin{tabular}{lcccc}
\hline & Estimate & SE & P & Result \\
\hline $\begin{array}{l}\text { Knowledge } \\
\text { Sharing } \rightarrow\end{array}$ & .894 & .047 & $* * *$ & Supported \\
$\begin{array}{l}\text { Innovative } \\
\text { behavior }\end{array}$ & & & & \\
$\begin{array}{l}\text { Innovative } \\
\text { Behavior } \rightarrow\end{array}$ & .841 & .056 & $* * *$ & Supported \\
Business \\
Performance
\end{tabular}

\subsection{The Effect of Knowledge Sharing on Innovative Behavior}

These five dimensions reflect Organ's (1988) original concept of Organizational citizenship behavior [16]. Knowledge sharing is an OCB activity or pro-social behavior that is not explicitly rewarded, individuals within and between organizations are committed to disseminating and acquiring knowledge [17]. Knowledge sharing in the workplace is the dissemination or exchange of explicit or tacit knowledge, ideas, experiences, skills, or technology 
between employees, individuals or groups. Such knowledge can be transferred from top to bottom, bottom to top or horizontally. In sharing knowledge, participants interact with each other both face-to-face and non-contact, such as written documents or virtual communities [16]. According to the estimation results, knowledge sharing has a significant positive effect on business performance. In a study developed by [18] and [19], it is explained that the quality of knowledge sharing is an important resource for competitive advantage in work teams and is related to the extent of understanding in sharing knowledge, openness in the distribution of experiences, interpersonal trust ties, the intensity of sharing and the criteria for information being shared. Organizations must always be ready to face changes and dynamics of the environment. The work method in the form of a work team that synergizes is the organization's preferred strategy to share interpersonal potential in order to produce reliable solutions in dealing with the dynamics of these changes [20]. In the fast changing era, the organization is required to always be innovative, orienting to outcome, and appreciating the existence and participation of members who help the organization to achieve it [21]. It was explained by [22] that leaders who apply innovative performance will push their employees or work groups to complete their jobs more efficiently, which later enables the company to achieve excellent performance. The capability to change the existing ideas into new concept and then to implement this concept in different way from competitors is absolutely needed for the existence of the company [10]. Regarding the implementation of $\mathrm{KBV}$ in organizations, according to [23] the main challenge is to build and maintain the continuity of knowledge management by utilizing the sophistication of information technology in work coordination, knowledge sharing and knowledge integration to achieve productive work results. Various activities within business organizations, including sharing knowledge, will strengthen organizational and interorganizational ties due to coordination, cohesion, trust, commitment, desire to share and helping behavior such as meaning in organizational citizenship behavior (OCB). The impact of this behavior between and between organizations gain new knowledge, whether obtained through tacit or explicit knowledge. It is through this social process that ambidexterity learning occurs, where organizational members explore and exploit each other's knowledge. The ability of organizational members to use each other's knowledge effectively is bound in social contexts that shape the process of socialization and conscious learning to be from and through others as members who are involved in working together in overcoming tasks and challenges and increasing organizational innovation [4]. Creative ideas that arise during and after knowledge sharing, are able to improve innovative performance, in improving the quality and competitiveness of the organization with management support [10].

\subsection{The Effect of Innovative Behavior on Business Performance}

The appearance of bright ideas and ideas, if the leader and subordinates are always proactive in seeking new knowledge and experiences, sharing information, engaging in discussions, seeking criticism and feedback. These are some of the behaviors of leaders who are always learning-oriented. To deal with changes and developments of the times, individuals who are always adaptable, flexible and proactively adapt and have a high curiosity in increasing competence, they are the ones who always flow with the times and are not outdated [12]. In the competitive era, companies that have unique differences in products, services, marketing, distribution, production processes, will be able to maintain customer loyalty and win competitive advantages. Knowledge sharing can play a role in achieving collaborative innovation and solutions. knowledge sharing not only changes employee attitudes, increases competence in aligning with the dynamics of organizational strategy, but also facilitates the transformation of individual knowledge into organizational knowledge, resulting in technological capabilities, organizational effectiveness, increasing trust building of organizational work team members and the ability to achieve competitive advantage [24]. The capabilities of organizational members in the acquisition and implementation of knowledge will facilitate the formation of value co-creation collaboration among members of the organization in the application of competencies through continuous improvement processes and innovation. Organizational members develop their competencies through developmental interactions that lead to increasing individual proficiencies so that knowledge workers and talented workers are formed. Knowledge-based human resources are able to create value by finding novelty in the work process so that they are able to form creative and innovative work teams. Creative and innovative work teams are able to provide idiosyncratic power to work processes and work results, so they are not easily imitated by competitors. Organization members who are able to find new breakthroughs and implement creative ideas can improve the organization's business performance [25]. 


\section{CONCLUSION}

This research contributes to strengthening the first, Knowledge Based View which is the development of the resource based view. RBV provides the view that organizations need to develop unique resources as core competencies to achieve business performance excellence [26]. These core competencies are embedded in human resources, namely knowledge, skills and behaviors that are not easily imitated by competitors [3].

\section{REFFERENCES}

[1] Z. Wang, N. Wang, and H. Liang, "Knowledge Sharing, Intellectual Capital and Firm Performance," Management Decision, vol. 52, no. 2, pp. 230-258, 2014, doi: 10.1108/md-022013-0064

[2] L. Marouf, "The Role of Knowledge Sharing Culture In Business Performance," VINE Journal of Information and Knowledge Management Systems, vol. 46, no. 2, pp. 154-174, 2016, doi: 10.1108/vjikms-10-2014-0061

[3] S. K. Singh, S. Gupta, Busso, D., and S. Kamboj, "Top Management Knowledge Value, Knowledge Sharing Practices, Open Innovation and Organizational Performance, Journal of Business Research, 2019, doi: 10.1016/j.jbusres.2019.04.040

[4] Muhammed, S., and Zaim, H. (2020). Peer knowledge sharing and organizational performance: the role of leadership support and knowledge management success. Journal of Knowledge Management, 24(10), 2455-2489. doi: 10.1108/jkm-03-2020-0227

[5] Y.W. Chiu, and Y.C. Chien, "The Effect of Knowledge Sharing on Organizational Performance: Organizational Learning as Mediator," International Journal of Information Technology and Business Management, vol. 36, no. 1,2015

[6] Z. Wang, and N. Wang, "Knowledge Sharing, Innovation And Firm Performance, Expert Systems with Applications, vol. 39, no. 10, pp. 8899-8908, 2012 doi: 10.1016/j.eswa.2012.02.017

[7] E. Sulistiyani, U. Udin, and E. Rahardja, "Examining The Effect Of Transformational Leadership, Extrinsic Reward, and Knowledge Sharing On Creative Performance Of Indonesian
SMEs," Quality Access to Success, vol. 19, no. 167, pp. 63-67, 2018

[8] E. Sulistiyani, and A.T. Ferdinand, "Value Oriented Developmental Interaction Capability: A Driver for Teamwork Performance," Business: Theory and Practice, vol. 19(0), pp. 300-308, 2018. doi: $10.3846 / \mathrm{btp} .2018 .30$

[9] T.M. Amabile, and M.G. Pratt, "The Dynamic Componential Model of Creativity and Innovation in Organizations: Making Progress, Making Meaning," Research in organizational behavior, vol. 36, pp. 157-183, 2016, doi: 10.1016/j.riob.2016.10.001

[10] E. Sulistiyani, Azizah, I. Nurkhayati, and Winarto, "Enhancing Innovative Performance through Extra-role Creativity: An Empirical Study," The International Journal Of Business \& Management, vol. 9, no. 8, pp. 9-17, 2021, doi: 10.24940/theijbm/2021/v9/i8/BM2108-002

[11] D.E. Krause, "Influence-based Leadership as a Determinant of the Inclination to Innovate and of Innovation-related Behaviors: An Empirical Investigation," Leadership Quarterly, vol. 15, no. 1, pp. 79-102, 2004

[12] E. Sulistiyani, and Azizah, "Beberapa Determinan Perilaku Kerja Inovatif Pada Karyawan Industri Batik Skala Ekspor Surakarta," Paper presented at the Seminar Nasional Terapan Riset Inovatif (SENTRINOV) 2017, Politeknik Negeri Malang, 2017

[13] J. de Jong, and D. den Hartog, "Measuring Innovative Work Behaviour," Creativity And Innovation Management, vol. 19, no. 1, pp. 2336, 2010, doi: 10.1111/j.14678691.2010.00547.x

[14] O. Jansen, “Transformationeel Leiderschap En Innovatie Fwerkgedrag Van Medewerkers: Een Kwestie Van Benaderbaarheid Van De Leider," Gedrag and Organisatie, vol. 15, pp. 275-293, 2002

[15] J. F. Hair, W. C. Black, B. J. Babin, and R. E. Anderson, Multivariate Data Analysis. London: Pearson Education Limited, 2014

[16] H. A. Al-Zu'bi, "Organizational Citizenship Behavior and Impacts on Knowledge Sharing: An Empirical Study," International Business Research, vol. 4, no. 3, pp. 221-227, 2011, doi: 10.5539/ibr.v4n3p221 
[17] S. H. Han, G. Seo, S. W. Yoon, and D.Y. Yoon, "Transformational leadership and knowledge sharing and OCB," Journal of Workplace Learning, vol. 28, no. 3, pp. 130-149, 2016. doi: 10.1108/JWL-09-2015-0066

[18] J. Olaisen, and O. Revang, "Working Smarter and Greener: Collaborative Knowledge Sharing in Virtual Global Project Teams," International Journal of Information Management, vol. 37, pp. 1441-1448, 2017

[19] A. Sarkheyli, R.A. Alias, N.F. Ithnin, and M.D. Esfahani, "Dimmensions of Knowledge Sharing Quality: An Empirical Investigation," Journal od Research and Innovation in Information Systems, 2013.

[20] A. Cabrera, W. C. Collins, and J. F. Salgado, "Determinants of Individual Engagement in Knowledge Sharing," The International Journal of Human Resource Management, 17(2), 245264, 2006, doi: 10.1080/09585190500404614

[21] S. Z. Butt, "Determinants of innovative Work Behavior: Organizational and Individual Characteristics Assessment of Military Leadership," National Institute of Psychology, Quaid-i-Azam University Islamabad, 2006

[22] N. Ramamoorthy, P. C. Flood, T. Slattery, and R. Sardessai, "Determinants of Innovative Work Behaviour Development and Test of an Integrated Model" Creativity and Innovation Management, vol. 14, no, 2, 2005

[[23] R. M. Grant, "Toward A Knowledge-Based Theory of The Firm," Strategic Management Journal, vol. 17(Winter Special Issue), pp. 109122, 1996

[24] A. G. Kassa, and G. T.Tsigu, "Corporate Entrepreneurship, Employee Engagement and Innovation: a Resource-Basedview and a Social Exchangetheory Perspective," International Journal of Organizational Analysis, ahead-ofprint(ahead-of-print), 2021, doi: 10.1108/IJOA05-2020-2172

[25] E. Sulistiyani, Peran Developmental Interaction Capability dalam Upaya Strategik Meningkatkan Kinerja Tim. (Doktoral), Diponegoro University, Semarang, 2018

[26] J. B. Barney, "Firm Resources and Sustained Competitive Advantage," Advances in Strategic Management, vol. 17, pp. 203-227, 1991 